\section{KEPEMIMPINAN \& KETERIKATAN PEGAWAI di Perguruan Tinggi}

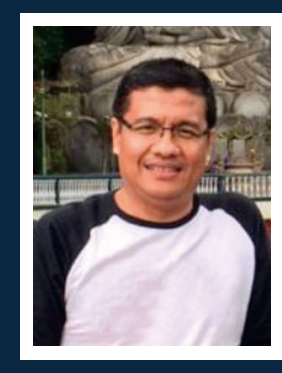

Alhamdulillah, Puji syukur saya kepada Allah SWT dimana akhirnya buku ini bisa diterbitkan.

Buku ini berisi hasil penelitian saya selama menempuh studi program Doktor IImu Manajemen dengan konsentrasi pada bidang Manajemen Sumber Daya Manusia di Universitas Padjadjaran, Bandung dengan bahasan seputar permasalahan SDM yang dialami oleh Tenaga Kependidikan (Tendik) yang terjadi di lingkungan Perguruan Tinggi Negeri.

Fokus bahasan pada faktor keterikatan pegawai yang dipengaruhi oleh faktor kepemimpinan dengan pemberdayaan dan kontrak psychologis sebagai variabel intervening.

Secara umum pada pegawai tenaga kependidikan ditemukan bahwa kepemimpinan dikategorikan efektif, ini menggambarkan bahwa tanggapan pegawai dalam hal kepemimpinan yang meliputi dimensi leader-member relations, participative leader dan leader's position power sudah sesuai dengan apa yang dirasakan. Namun masih ditemukan tanggapan pegawai yang menunjukkan bahwa peran kepemimpinan baru berada pada kategori cukup atau belum efektif yaitu indikator kerjasama pada dimensi leader-member relations dan indikator mendengarkan saran bawahan, membuat bawahan merasa bebas dan menerima kritik dari bawahan pada dimensi participative leader.

Buku ini sangat menarik untuk dibaca oleh akademisi ataupun praktisi yang berkecimpung dalam bidang Manajemen Sumber Daya Manusia. In shaa Allah buku ini dapat memberikan manfaat bagi pembaca
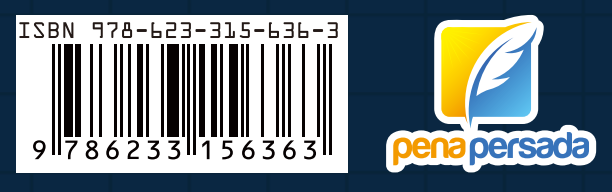

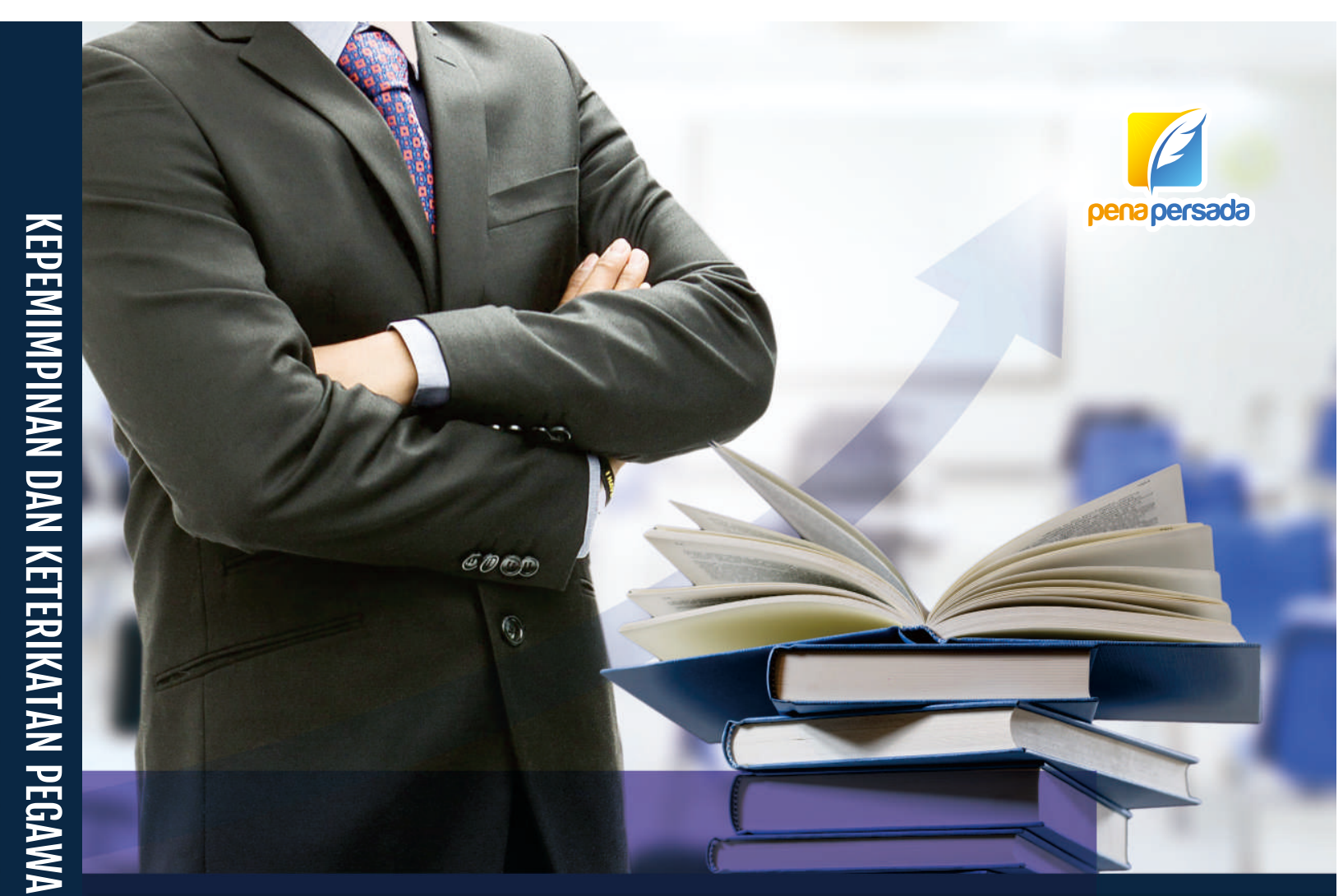

Dr. Abdhy Aulia Adnans, MM

KEPEMIMPINAN \& KETERIKATAN PEGAWAI di Perguruan Tinggi 


\title{
KEPEMIMPINAN DAN KETERIKATAN PEGAWAI Di Perguruan Tinggi
}

\author{
Dr. Abdhy Aulia Adnans, MM
}

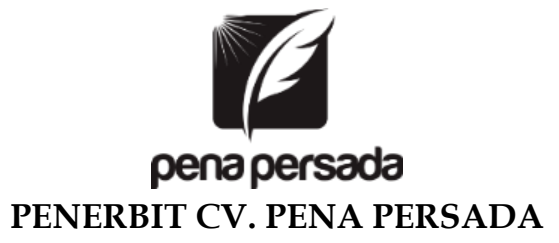




\title{
KEPEMIMPINAN DAN KETERIKATAN PEGAWAI \\ Di Perguruan Tinggi
}

\author{
Penulis: \\ Dr. Abdhy Aulia Adnans, MM
}

ISBN : 978-623-315-636-3

\section{Editor:}

Tri Hidayati

Design Cover:

Retnani Nur Brilliant

Layout:

Nisa Falahia

\section{Penerbit CV. Pena Persada}

Redaksi:

Jl. Gerilya No. 292 Purwokerto Selatan, Kab. Banyumas Jawa Tengah

Email: penerbit.penapersada@gmail.com Website: penapersada.com Phone: (0281) 7771388

\section{Anggota IKAPI}

All right reserved

Cetakan pertama: 2021

Hak Cipta dilindungi oleh undang-undang. Dilarang memperbanyak karya tulis ini dalam bentuk apapun tanpa izin penerbit 


\section{KATA PENGANTAR}

Puji syukur saya panjatkan kepada Tuhan Yang Maha Esa, karena atas berkat dan rahmat-Nya, saya dapat menyelesaikan buku ini. Penulisan buku merupakan buah karya dari pemikiran penulis yang diberi judul "Kepemimpinan dan Keterikatan Pegawai di Perguruan Tinggi". Saya menyadari bahwa tanpa bantuan dan bimbingan dari berbagai pihak sangatlah sulit bagi saya untuk menyelesaikan karya ini. Oleh karena itu, saya mengucapkan banyak terima kasih pada semua pihak yang telah membantu penyusunan buku ini. Sehingga buku ini bisa hadir di hadapan pembaca.

Buku ini bertujuan untuk mengungkap implikasi kepemimpinan terhadap keterikatan pegawai melalui pemberdayaan dan kontrak psikologis pada tenaga pendidikan di Perguruan Tinggi Negeri.

Kajian dalam buku ini dilakukan terhadap seluruh unit bagian yang ada di lingkungan Universitas Padjadjaran terdiri dari 320 responden pegawai tenaga kependidikan yang berstatus Pegawai Negeri Sipil, menggunakan analisis deskriptif dengan tabel distribusi frekuensi dan analisis verifikatif yang memanfaatkan Structural Equation Modeling (SEM) dengan pendekatan Partial Least Square (PLS) yang mana data diolah melalui software SMART PLS 3.

Secara keseluruhan, buku ini mengungkap bahwa keterikatan pegawai dapat dicapai apabila kepemimpinan, pemberdayaan dan kontrak psikologis memiliki peran yang cukup dominan dalam memenuhi keseluruhan aspek keterikatan pegawai.

Penulis menyadari bahwa buku ini masih jauh dari kesempurnaan. Oleh karena itu kritik dan saran yang membangun sangat dibutuhkan guna penyempurnaan buku ini. Akhir kata saya berharap Tuhan Yang Maha Esa berkenan membalas segala kebaikan semua pihak yang telah membantu. Semoga buku ini akan membawa manfaat bagi pengembangan ilmu Manajemen Sumber Daya Manusia. 


\section{DAFTAR ISI}

KATA PENGANTAR iii

DAFTAR ISI

BAB I PENDAHULUAN 1

A. Tantangan Manajemen Sumber Daya Manusia di Perguruan Tinggi $\quad 1$

B. Faktor yang Menentukan Kualitas Perguruan Tinggi 4

C. Persoalan tentang Kapabilitas dan Perilaku Pegawai 6

D. Perspektif Teori 14

E. Metodologi 16

BAB 2 KONSEP KEPEMIMPINAN 28

BAB 3 KONSEP PEMBERDAYAAN 33

BAB 4 TEORI TENTANG KONTRAK PSIKOLOGIS 38

BAB 5 TEORI TENTANG KETERIKATAN PEGAWAI 44

BAB 6 KAJIAN TEORITIS TENTANG KETERKAITAN

ANTARA KEPEMIMPINAN, PEMBERDAYAAN,

KONTRAK PSIKOLOGIS, DAN KETERIKATAN

PEGAWAI

52

A. Keterkaitan Kepemimpinan dan Pemberdayaan Pegawai 52

B. Keterkaitan Kepemimpinan dan Kontrak Psikologis 53

C. Keterkaitan Kepemimpinan dan Keterikatan Pegawai 54

D. Keterkaitan Pemberdayaan dan Keterikatan Pegawai 55

E. Keterkaitan Kontrak Psikologis dan Keterikatan Pegawai 56

BAB IV PEMODELAN TENTANG PENGARUH KEPEMIMPINAN PADA PEGAWAI 58

A. Gambaran Kepemimpinan, Pemberdayaan, Kontrak Psikologis

1. Variabel Kepemimpinan 58

2. Variabel Pemberdayaan 64

3. Variabel Kontrak Psikologis 70

4. Variabel Keterikatan Pegawai 76

5. Pengaruh Kepemimpinan Terhadap Pemberdayaan dan Kontrak Psikologis serta 
Dampaknya Terhadap Keterikatan Pegawai

Tenaga Kependidikan

6. Kecocokan Model

7. Model Pengukuran

82

B. Pengaruh Kepemimpinan Terhadap Pemberdayaan

C. Pengaruh Kepemimpinan Terhadap Kontrak Psikologis

D. Pengaruh Kepemimpinan Terhadap Keterikatan Pegawai Melalui Pemberdayaan Tenaga Kependidikan

E. Pengaruh Kepemimpinan Terhadap Keterikatan Pegawai Melalui Kontrak Psikologis Tenaga Kependidikan

F. Pengaruh Kepemimpinan Terhadap Keterikatan Pegawai

G. Pengaruh Pemberdayaan Terhadap Keterikatan Pegawai

H. Pengaruh Kontrak Psikologis Terhadap Keterikatan Pegawai 


\section{KEPEMIMPINAN DAN KETERIKATAN PEGAWAI Di Perguruan Tinggi}




\section{BAB I \\ PENDAHULUAN}

\section{A. Tantangan Manajemen Sumber Daya Manusia di Perguruan Tinggi}

Perguruan tinggi adalah lembaga atau institusi sebagai pengembang ilmu pengetahuan dan teknologi. Oleh karena itu fungsi perguruan tinggi sangat strategis dalam meningkatkan daya saing, baik daya saing SDM maupun daya saing bangsa. Perguruan tinggi dituntut untuk selalu melakukan perubahan menuju perbaikan pendidikan yang lebih maju dan berkualitas sesuai dengan tuntutan lingkungan global yang berubah cepat atau tidak menentu.

Di era pasar bebas, pengelolaan perguruan tinggi harus ditujukan untuk mengantisipasi kehidupan yang penuh ketidakpastian dan penuh persaingan. Perguruan tinggi yang tidak dapat mempertahankan mutunya akan kalah dalam berbagai persaingan. Perkembangan perguruan tinggi di Indonesia khususnya Perguruan Tinggi Swasta (PTS) sangat pesat. Data Kemenristekdikti menunjukkan, saat ini jumlah perguruan tinggi di Indonesia mencapai 4.312 institusi, yang terdiri atas 3.940 PTS dan 372 PTN.

Perencanaan jangka panjang pendidikan tinggi di Indonesia yang tertuang dalam strategi jangka panjang pendidikan tinggi (Higher Education Long Term Strategy/HELTS), pemerintah telah mengubah peran Ditjen Dikti dari regulator dan eksekutor menjadi pemberdaya (empower), fasilitator dan motivator. Perubahan dimulai dengan mengganti Kerangka Pengembangan Pendidikan Tinggi Jangka Panjang (KPPTJP) dengan HELTS, karena perubahan paradigma pengelolaan negara yang semula sentralisasi menjadi desentralisasi dan juga sebagai tindakan penyelamatan pendidikan nasional. Selain itu, faktor penting lain yang menentukan perubahan tersebut adalah kesiapan bangsa Indonesia dalam berkompetisi dengan 
Perguruan Tinggi Asing (PTA), sebagai konsekuensi ikut serta dalam kesepakatan-kesepakatan perdagangan bebas. Depdiknas kemudian bergegas untuk menyiapkan Perguruan Tinggi agar dapat bertahan dan berkompetisi dengan PTA yang akan masuk ke Indonesia.

Membangun daya saing bangsa, merupakan suatu keharusan, inilah yang menjadi sentra perhatian pemerintah saat ini. Menurut pemerintah, kontribusi Perguruan Tinggi pada pengembangan daya saing bangsa dapat ditingkatkan apabila "kesehatan" organisasi pendidikan tinggi baik. Kemudian dalam kerangka HELTS ditekankan pula bahwa dengan memberikan otonomi kepada perguruan tinggi, diharapkan dapat dihasilkan lulusan yang berkualitas, terjadinya pengembangan dan penyebarluasan ilmu pengetahuan, teknologi dan seni, tumbuhnya peran aktif perguruan tinggi dalam proses pengembangan budaya bangsa serta terjadinya peningkatan kualitas layanan kepada masyarakat.

Universitas Padjadjaran merupakan salah satu perguruan tinggi negeri terbaik di Indonesia (ranking 12 versi webometrics Juli 2012 dan meningkat pada ranking ke-7 dari 100 versi (Webometrics, Ranking Web of Universities, Nov 2014. Saat ini, Unpad berstatus sebagai Perguruan Tinggi Negeri Badan Hukum. PTN Badan Hukum ini tercantum dalam Undang-Undang Nomor 12 Tahun 12 tentang Pendidikan Tinggi. Pada pasal 65 UU tersebut disebutkan, penyelenggaraan otonomi perguruan tinggi dapat diberikan secara selektif berdasarkan kinerja oleh Menteri kepada PTN. Bentuk otonomi yang dimaksud terdiri dari PTN yang menerapkan pola Pengelolaan Keuangan Badan Layanan Umum (PK BLU) atau PTN Badan Hukum. Unpad telah melaksanakan otonomi PK BLU sejak 15 September 2008, dan kini memperoleh mandat untuk meningkatkan otonomi menjadi PTN Badan Hukum. Peraturan Pemerintah Nomor 80 Tahun 2014 tentang Penetapan Unpad sebagai Perguruan Tinggi Negeri Badan Hukum ditandatangani Presiden RI, 
Susilo Bambang Yudhoyono, pada 17 Oktober 2014. Setelah itu, Peraturan Pemerintah Nomor 51 Tahun 2015 tentang statuta (anggaran dasar) Universitas Padjadjaran ditandatangani Presiden RI, Joko Widodo, pada 22 Juli 2015. Kepercayaan pemerintah memberikan mandat kepada Unpad menjadi PTN Badan Hukum merupakan "buah" dari perjuangan panjang para pengelola Unpad menjaga kualitas serta prestasi para mahasiswanya yang harus siap menghadapi persaingan yang ketat baik secara nasional maupun internasional.

Sebagai satuan pendidikan penyelenggara pendidikan tinggi, perguruan tinggi dapat berbentuk akademi, politeknik, sekolah tinggi, institut, atau universitas, yang mana di dalamnya ada dua profesi yang sering disebut dengan pendidik atau dosen dan tenaga kependidikan (UU No. 20 Tahun 2003/Sisdiknas).

Tenaga kependidikan atau biasa disebut pegawai merupakan anggota masyarakat yang mengabdikan diri dan diangkat untuk menunjang penyelenggaraan pendidikan. Tenaga kependidikan bertugas melaksanakan administrasi, pengelolaan, pengembangan, pengawasan, dan pelayanan teknis untuk menunjang proses pendidikan pada satuan pendidikan (UU No. 20 Tahun 2003/Sisdiknas).

Pada proses pelayanan seorang pegawai terhadap pengguna jasa layanan atau stakeholder perguruan tinggi dalam hal ini dosen, mahasiswa dan para pengguna jasa layanan lainnya secara langsung merupakan produk jasa yang dapat dilihat, didengar, dirasakan dan diamati oleh pengguna jasa layanan. Produk jasa di universitas bukanlah akhir dari pelayanan akan tetapi produk itu mulai dapat dirasakan sejak pengguna jasa layanan datang sampai dengan selesai pelayanan dalam arti sampai kebutuhan ataupun permasalahan yang dihadapi pengguna jasa layanan dapat terselesaikan. Karena proses pelayanan yang dilakukan oleh seorang pegawai merupakan produk jasa itu sendiri, maka seorang pegawai harus memiliki kompetensi dan mampu memberikan kemampuan terbaik yang dimilikinya. Keadaan ini menjadikan 
posisi pegawai memiliki peran yang penting dalam fungsinya memberikan pelayanan terhadap pengguna jasa layanan.

\section{B. Faktor yang Menentukan Kualitas Perguruan Tinggi}

Faktor eksternal dan internal akan berpengaruh terhadap pengelolaan internal perguruan tinggi yang efektivitasnya ditentukan antara lain oleh kepemimpinan, kematangan subordinat, tata kelola, pemberdayaan yang seluruhnya sesuai dengan sasaran, tujuan dan budaya organisasi. Selain mengelola subordinat, pemimpin Perguruan Tinggi juga "dikelola" oleh atasannya yaitu Yayasan Penyelenggara Perguruan Tinggi bagi PTS atau Wali Amanat bagi PTN.

Berdasarkan hal tersebut, maka efektivitas, sebagai ukuran keberhasilan perguruan tinggi, perlu dikaji ulang sejalan dengan penerapan Good University Governance (GUG) yang diadopsi dari Good Corporate Governance (GCG) sebagai tata laksana yang benar dalam pengelolaan perusahaan.

Untuk terus dapat mempertahankan atau memperbaiki peringkat sebagai salah satu perguruan tinggi terbaik di negeri ini dan mampu menghadapi persaingan global Universitas Padjadjaran harus didukung oleh sumber daya manusia yang berkualitas dalam hal ini tenaga kependidikan atau yang lebih sering disebut dengan pegawai yang mempunyai fungsi penting untuk menunjang proses pendidikan pada satuan pendidikan.

Terkait dengan hal tersebut pasal 17 Ayat 2 UU No. 43 Tahun 1999 mengenai Pengangkatan Dalam Jabatan, maka di Universitas Padjadjaran menganut ketentuan (1) PNS diangkat dalam jabatan dan pangkat, (2) Pengangkatan dalam jabatan dilaksanakan berdasarkan prinsip profesionalisme, sesuai (a) Kompetensi, (b) Prestasi kerja, (c) Jenjang pangkat, (d) Syarat objektif lainnya. Universitas Padjadjaran juga mensyaratkan (1) setiap PNS punya peran yang jelas dalam pencapaian misi organisasi, (2) antara jabatan dan pegawai sesuai kompetensinya, (3) penilaian kinerja objektif (SKI-standar kinerja individu), dan (4) PNS jelas alur kariernya. 
Gambar 1.1. di bawah ini menjelaskan sistem pembinaan PNS di Universitas Padjadjaran.

\section{Gambar 1.1. Framework Pembinaan PNS}

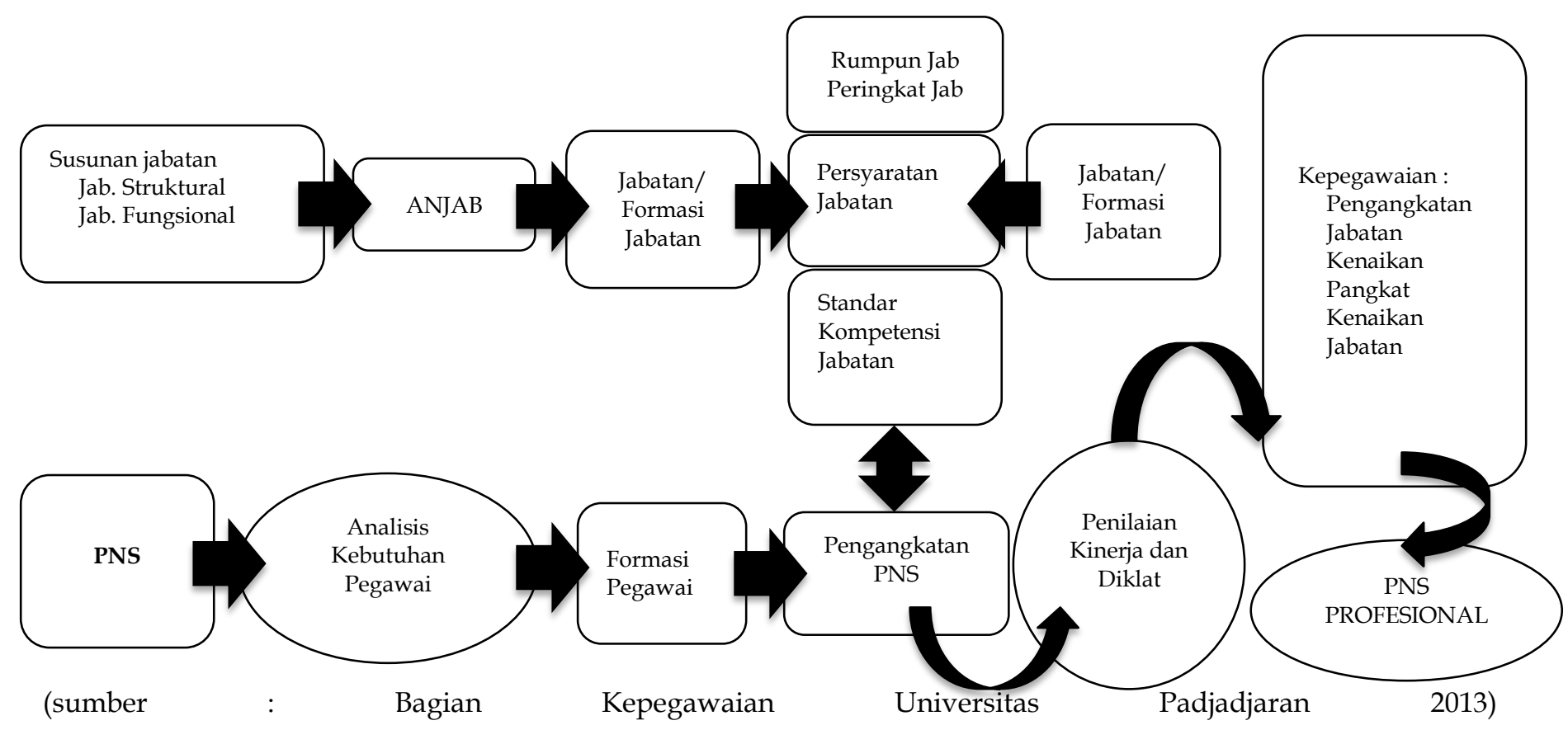


Dari gambar 1.1. di atas, terlihat bahwa sistem pembinaan PNS yang dimiliki oleh Universitas Padjadjaran untuk menghasilkan PNS yang profesional sudah baik dengan menganut kepada peraturan yang berlaku.

Selain sistem pembinaan PNS yang sudah dimiliki dan dilaksanakan dengan baik, sejak Juli 2013, PNS serta CPNS di lingkungan Kementerian Pendidikan dan Kebudayaan telah mulai diberikan tunjangan kinerja. Pemberian tunjangan kinerja berdasarkan Peraturan Presiden Nomor 88 Tahun 2013, dan Peraturan Menteri Pendidikan dan Kebudayaan Nomor 107 Tahun 2013 tentang Tunjangan Kinerja bagi Pegawai di Lingkungan Kementerian Pendidikan dan Kebudayaan. Tunjangan Kinerja diharapkan dapat memacu semangat kerja pegawai agar dapat bekerja dengan lebih giat, lebih efektif dan efisien, Selain itu, pemberian tunjangan kinerja pun diharapkan bisa meningkatkan kesejahteraan tiap-tiap pegawai.

\section{Persoalan tentang Kapabilitas dan Perilaku Pegawai}

Adanya sistem pembinaan yang baik dan tunjangan kinerja yang diberikan maka seharusnya profesionalitas pegawai sudah dilakukan dengan baik pula tetapi pada kenyataannya masih banyak persoalan yang dikeluhkan oleh pengguna jasa layanan terhadap layanan yang diberikan. Fenomena umum yang terjadi adalah keluhan dari pengguna jasa layanan tentang kapabilitas dan perilaku pegawai dalam memberikan pelayanan. Untuk mengetahui secara lebih spesifik tentang apa yang dikeluhkan oleh pengguna jasa layanan, maka dilakukan observasi pra survei dengan melakukan wawancara kepada beberapa pengguna jasa layanan. Dari hasil pra survei tersebut dapat diketahui beberapa keluhan pengguna jasa layanan terhadap layanan yang diberikan, keluhan tersebut adalah :

1. Keramahan

2. Kejelasan informasi

3. Kompetensi

4. Ketepatan waktu 


\section{Cepat tanggap dan \\ 6. Kemudahan prosedur}

Untuk menindaklanjuti fenomena yang tersebut di atas, maka dilakukan survei awal terhadap beberapa unit kerja di Universitas Padjadjaran pada bulan Februari 2015 yang bertujuan untuk mendapatkan informasi mengenai kondisi pegawai sehubungan dengan fenomena yang terjadi. Survei dilakukan dengan cara melakukan observasi, diskusi dan wawancara terhadap pegawai tenaga kependidikan.

Dari survei yang dilakukan maka ditemukan faktorfaktor yang menjadi sebab adanya fenomena tersebut di atas. Faktor-faktor tersebut adalah :

1. Kepemimpinan, keluhan pegawai terhadap transparansi informasi yang berhubungan dengan pengembangan karier. Pegawai tidak mengetahui hal apa yang menjadi dasar pertimbangan pimpinan kepada seorang pegawai untuk mendapat kesempatan dalam hal pengembangan karir pegawai tersebut. Padahal secara umum yang harus diterapkan organisasi dalam hal pengembangan karier haruslah berdasarkan pada dimensi kemanusiaan, keorganisasian, pengembangan atau reposisi pegawai, keadilan, keterbukaan dan akuntabilitas serta berkelanjutan. Sering kali seorang pegawai berada sangat lama dalam satu posisi atau jabatan yang menghambat regenerasi atau pembaharuan, sehingga pegawai jenuh dan sulit untuk mengembangkan potensi diri yang dimiliki. Dalam hal ini sering kali pegawai menyalahkan pimpinan yang dianggap kurang tanggap terhadap keadaan yang mereka alami. Kondisi ini membuat pegawai merasa bahwa kepemimpinan yang dilaksanakan tidak efektif. Menurut Veithzal Rivai (2009), kepemimpinan adalah proses mengarahkan dan mempengaruhi aktivitas-aktivitas yang ada hubungannya dengan pekerjaan anggota kelompok atau kepemimpinan merupakan kemampuan untuk mempengaruhi, memberi inspirasi dan mengarahkan 
tindakan seseorang atau kelompok untuk mencapai tujuan yang diharapkan.

2. Pemberdayaan rendah, dapat dilihat dari pendelegasian tugas dan kredibilitas oleh pimpinan kepada pegawai dirasa masih kurang dalam hal memberikan kesempatan untuk pemecahan suatu masalah dan pemberian wewenang untuk merencanakan, mengendalikan, dan membuat keputusan tentang pekerjaan yang menjadi tanggung jawabnya, tanpa harus mendapatkan otorisasi secara eksplisit dari pimpinan di atasnya. Dampaknya adalah pegawai tidak optimal dalam menyelesaikan pekerjaan karena memiliki ketergantungan terhadap keputusan pimpinan. Pemberdayaan berarti untuk membantu orang meningkatkan rasa percaya diri mereka, mengatasi ketidakberdayaan mereka, dan memiliki antusiasme dan motivasi intrinsik untuk melakukan tugas-tugas (Blanchard et. al 2003).

3. Kontrak psikologis rendah, sering kali ditemukan seorang pegawai di rotasi, mutasi dan demosi dari posisi satu ke posisi lainnya secara tiba-tiba tanpa pemberitahuan ataupun sosialisasi terlebih dahulu dan kurangnya kesempatan yang diberikan untuk mengikuti pelatihan pengembangan diri. Hal ini tentunya membuat pegawai merasa kecewa dan merasa kurang dihargai yang akan berpengaruh terhadap hubungan antara pimpinan dan pegawai. Hal ini terkait juga dengan kontrak psikologis antara pimpinan dan bawahan, dimana terdapat ekspektasi atau harapan bawahan kepada pimpinan yang bersifat timbal balik mengenai apa yang menjadi kewajiban dan apa yang akan diberikan sebagai timbal balik satu sama lain untuk mencapai tujuan organisasi. Puncak dari kontrak psikologis adalah meningkatnya kepercayaan dan loyalitas yang tinggi antara pegawai dan pengusaha (Wilkens \& Nermerich , 2011). 
4. Keterikatan pegawai lemah, dimana sering terlihat pegawai hadir ke kantor tetapi kurang bersemangat dalam melakukan pekerjaannya, bekerja tidak optimal dan kurang termotivasi untuk memberikan kontribusi bagi keberhasilan organisasi dengan memberikan kemampuan terbaik yang mereka miliki. Lemahnya keterkaitan mereka pada pekerjaan yang dicirikan dengan perilaku memboroskan waktu kerja untuk kegiatan yang tidak berhubungan dengan pencapaian sasaran kerja organisasi dan melakukan tindakan yang tidak konsisten dengan sasaran kerja sehingga berdampak pada penurunan pencapaian kinerja organisasi sehingga menimbulkan keluhan dari pengguna jasa layanan. Pegawai yang mempunyai keterikatan yang kuat mampu memberikan kemampuan terbaik mereka untuk membantu sukses dari serangkaian manfaat nyata bagi organisasi. Keterikatan pegawai disebut juga sebagai komitmen atau motivasi merujuk kepada kondisi psikologis pegawai yang memiliki perhatian terhadap keberhasilan organisasi dan dapat memberikan hasil kinerja yang lebih tinggi (Mercer, 2011).

Sehubungan dengan hal tersebut, berikut ini disajikan tabel lama masa jabatan pegawai di Universitas Padjadjaran.

Tabel 1.1. Lama Masa Jabatan Pegawai

\begin{tabular}{|c|c|c|}
\hline Masa Jabatan & Jumlah Pegawai & $\%$ \\
\hline < 5 tahun & 405 & $25 \%$ \\
\hline 5-9 tahun & 793 & $49 \%$ \\
\hline $\mathbf{1 0 - 1 4}$ tahun & 332 & $21 \%$ \\
\hline $\mathbf{1 5 - 1 9}$ tahun & 64 & $4 \%$ \\
\hline$>$ 20 tahun & 14 & $1 \%$ \\
\hline Grand Total & $\mathbf{1 6 0 8}$ & $\mathbf{1 0 0} \%$ \\
\hline
\end{tabular}

Sumber : Kepegawaian Unpad 2015 (Data diolah) 
Hasil pengolahan data pada tabel 1.1. di atas menunjukkan bahwa lama masa jabatan seorang pegawai cukup bervariasi, persentase terbesar $49 \%$ adalah lama masa jabatan pegawai dalam kurun waktu 5-9 tahun, lama masa jabatan 10-14 tahun sebesar 21\%, lama masa jabatan 15-19 tahun sebesar $4 \%$ dan lama masa jabatan > 20 tahun sebesar $1 \%$. Lama masa jabatan dengan interval 5-15 tahun di dominasi oleh jabatan fungsional umum atau staf pelaksana dimana 389 pegawai dengan golongan/ruang III/b (data diolah) yang secara aturan sudah memenuhi syarat untuk menduduki jabatan struktural. Fenomena ini mengindikasikan bahwa kurangnya perhatian pimpinan terhadap pengembangan karir pegawai dalam hal ini rotasi dan promosi, dimana terlihat lamanya seorang pegawai dalam masa jabatan tertentu dapat menghambat potensi pengembangan diri pegawai lain misalnya dalam hal pengembangan pengetahuan dan keterampilan atau nilai-nilai hubungan sosial.

Hal ini tentu akan berpengaruh terhadap pengembangan karir atau kesempatan dari pegawai-pegawai yang belum pernah menjabat dalam posisi tersebut, padahal masih banyak pegawai yang memiliki usia produktif dan mempunyai potensi untuk menduduki jabatan tersebut.

Selanjutnya pada tabel berikut dapat dilihat jumlah pegawai yang pernah mengikuti pelatihan yang bertujuan untuk pengembangan diri dan kompetensi sebagai sarana untuk meningkatkan keahlian pegawai tersebut dalam melaksanakan pekerjaannya.

Tabel 1.2.

Jumlah Pegawai yang Mengikuti Pelatihan Berdasarkan Unit Kerja

\begin{tabular}{lll}
\hline \multicolumn{1}{c}{ Unit Kerja } & Jumlah \\
\hline Fakultas Hukum & 43 \\
\hline Badan Pengelola Usaha & 14 \\
\hline Fakultas Ekonomi dan Bisnis & 115 \\
\hline UPT Teknologi Informasi & 12 \\
\hline
\end{tabular}




\begin{tabular}{|c|c|}
\hline Fakultas Kedokteran & 77 \\
\hline UPT Kearsipan & 14 \\
\hline Fakultas MIPA & 104 \\
\hline UPT Kehumasan & 5 \\
\hline Fakultas Pertanian & 65 \\
\hline UPT Pengelola Lingkungan & 9 \\
\hline Fakultas Kedokteran Gigi & 39 \\
\hline UPT Kerjasama & 9 \\
\hline Fakultas Ilmu Sosial dan Ilmu Politik & 62 \\
\hline Lembaga Pembelajaran dan Penjamin Mutu & 4 \\
\hline Fakultas Ilmu Budaya & 45 \\
\hline $\begin{array}{l}\text { Lembaga Pengembangan Kemahasiswaan dan } \\
\text { Alumni }\end{array}$ & 12 \\
\hline Fakultas Psikologi & 63 \\
\hline UPT Perpustakaan & 18 \\
\hline Fakultas Peternakan & 60 \\
\hline Fakultas Ilmu Komunikasi & 62 \\
\hline Program Pascasarjana & 10 \\
\hline Fakultas Keperawatan & 41 \\
\hline Fakultas Perikanan dan Ilmu Kelautan & 33 \\
\hline $\begin{array}{l}\text { Biro Sumber Daya Manusia, Hukum dan Tata } \\
\text { Kelola }\end{array}$ & 97 \\
\hline Biro Pembelajaran dan Kemahasiswaan & 31 \\
\hline Biro Keuangan dan Barang Milik Negara & 49 \\
\hline Biro Perencanaan dan Sistem Informasi & 36 \\
\hline $\begin{array}{l}\text { Lembaga Penelitian dan Pengabdian Kepada } \\
\text { Masyarakat }\end{array}$ & 15 \\
\hline Fakultas Teknologi Industri Pertanian & 50 \\
\hline Satuan Pengawas Internal & 7 \\
\hline Fakultas Farmasi & 43 \\
\hline Fakultas Teknik Geologi & 41 \\
\hline Total & 1285 \\
\hline
\end{tabular}

Sumber : Kepegawaian Unpad 2015 (Statistik diolah) 
Berdasarkan tabel 1.2. di atas dapat dilihat jumlah pegawai yang sudah mengikuti pelatihan yang bertujuan untuk pengembangan diri dan kompetensi sebanyak 1285 orang dari total pegawai sebanyak 1608 orang atau sebesar $80 \%$. Hal ini menunjukkan bahwa sejumlah pegawai sudah memiliki kompetensi tambahan yang tentunya akan menjadi modal untuk meningkatkan kinerja dan karier pegawai tersebut.

Dari data kepegawaian, hasil survei dan wawancara di lapangan ditemukan bahwa secara jumlah total keseluruhan pegawai yang telah mengikuti pelatihan untuk pengembangan diri dan kompetensi terbilang cukup besar yaitu mencapai $80 \%$ tetapi secara individu perorangan jumlahnya masih sangat terbatas, yaitu orang atau individu yang ditugaskan untuk mengikuti pelatihan teridentifikasi lebih banyak individu/ orang yang sama sebelumnya sudah pernah mengikuti pelatihan tersebut atau dengan kata lain pegawai yang ditugaskan untuk mengikuti pelatihan untuk pengembangan diri dan kompetensi adalah pegawai/orang yang sudah pernah ditugaskan sebelumnya yang mendapatkan kesempatan berkali-kali. Kondisi ini menyebabkan pegawai lain tidak mempunyai kesempatan yang sama untuk diikutsertakan atau ditugaskan dalam mengikuti pelatihan yang bertujuan untuk pengembangan diri dan meningkatkan kompetensi yang nantinya akan berguna untuk pengembangan karier pegawai ke depannya. Fenomena ini mengindikasikan bahwa pemimpin memiliki rasa percaya yang rendah terhadap bawahan sehingga hanya pegawai tertentu yang ditugaskan untuk mengikuti pelatihan, tidak terlalu mengenal bawahan karena kurangnya komunikasi dan bergaul secara informal sehingga tidak mengetahui potensi yang dimiliki bawahan, pemimpin lebih mengutamakan otoritas dan perlakuan pemimpin yang dirasa kurang adil dalam memberikan kesempatan kepada bawahan dalam meningkatkan dan mengembangkan potensi diri yang dibutuhkan. 
Keadaan di atas berhubungan dengan sisi pemberdayaan terhadap pegawai, yang berdampak terhadap motivasi untuk melakukan pekerjaan menjadi rendah, merasa tidak berarti dan tidak mempunyai pengaruh dalam pekerjaan karena kesempatan yang dirasa kurang untuk ikut dalam pelatihan yang bertujuan untuk pengembangan diri dan kompetensi dan juga pada inisiatif pegawai yang rendah untuk mengambil keputusan yang diperlukan tanpa persetujuan dari pimpinan.

Sehubungan dengan hal tersebut, kontrak psikologis antara pimpinan dan bawahan menjadi terganggu, dimana harapan pimpinan dan bawahan yang bersifat timbal balik yaitu pimpinan mempunyai harapan kepada pegawai untuk melakukan pekerjaan secara optimal, memberikan kemampuan terbaik yang dimiliki kepada perusahaan dan sebaliknya pegawai mempunyai harapan kepada pimpinan untuk memenuhi kebutuhan pegawai, seperti kenyamanan dalam bekerja dan pengembangan karier menjadi tidak terealisasi dengan baik.

Terkait dengan pemberdayaan dan kontrak psikologis maka akan berhubungan pula dengan keterikatan pegawai terhadap organisasi. Apabila pegawai merasa kurang dilibatkan dalam wewenang pekerjaan, terhambat dalam pengembangan diri untuk pengembangan karier dan harapanharapan yang tidak terpenuhi maka keterikatan pegawai terhadap organisasi juga akan berkurang, pegawai akan melakukan pekerjaan dengan semampunya saja tanpa mau bekerja lebih keras untuk memberikan kemampuan terbaiknya bagi organisasi.

Berdasarkan uraian yang telah dijelaskan diatas, terlihat bahwa kepemimpinan, pemberdayaan, kontrak psikologis dan keterikatan pegawai pada tenaga kependidikan atau pegawai di Universitas Padjadjaran sangat menarik untuk dilihat keterikatannya terhadap organisasi, sehingga penulis perlu untuk mengkaji lebih lanjut mengenai implikasi kepemimpinan terhadap keterikatan pegawai melalui 